JADARA

Volume 5 | Number 3

Article 9

November 2019

\title{
Educational, Psychological, and Occupational Aspects of the Nonwhite Deaf Population
}

Frank G. Bowe

Central Susquehanna Intermediate Unit, Bloomsburg State College, Pennsylvania

Follow this and additional works at: https://repository.wcsu.edu/jadara

Recommended Citation

Bowe, F. G. (2019). Educational, Psychological, and Occupational Aspects of the Nonwhite Deaf

Population. JADARA, 5(3). Retrieved from https://repository.wcsu.edu/jadara/vol5/iss3/9 


\section{EDUCATIONAL, PSYCHOLOGICAL, AND OCCUPATIONAL ASPECTS OF THE NONWHITE DEAF POPULATION}

BY FRANK G. BOWE, M.A.

My topic concerns a minority within a minority, perhaps the most misunderstood segment of the national deaf population. Whether Black, Puerto Rican, Indian, Oriental or of some other group, nonwhite deaf persons face a number of problems not commonly shared by their white deaf counterparts. We wish to consider some of these problems here. Remarks will be focused primarily on the Black deaf group, insofar as most of our data concerns this segment.

Nonwhite deaf persons are likely to be grossly under-educated, severely under-employed, and largely isolated from the larger deaf community as well as from the dominant hearing society (Bowe, 1971a). They number approximately 22,000, about one-tenth of the total deaf population (Bowe, 1971b).

\section{Educational Preparation}

The history of education for nonwhite deaf persons is in many respects a bleak and discouraging story. For most of the century and a half that deaf children have been educated in special schools in America, nonwhite deaf children have often been relegated to manifestly inferior schools for the deaf, especially in the South. Even in those institutions which were desegregated, few provisions were made for the disadvantaged backgrounds and special needs of children from inner cities and from reservations.

\footnotetext{
Adapted from a paper presented to the American Psychological Association's seventyninth convention in Washington, D.C., September 5, 1971.
}

Mr. Bowe is employed by the Central Susquehanna Intermediate Unit as teacher of a class of deaf children located in Bloomsburg State College, Bloomsburg, Pa.

Reprint requests to 150 Brown St., Lewisburg, Pa. 17837. 
As recently as 1949 , thirteen states maintained separate residential schools for white and Negro deaf children. By 1963, the total was eight (Babbidge, 1964). Only very recently have these remaining eight states desegregated their schools for the deaf.

The results of this neglect have now been documented (Bowe, 1971a,b). One study discovered that nonwhite deaf persons were twice as likely as the white deaf to have eight or fewer years of school attendance (Furfey and Harte, 1968). Another study found that twice as high a proportion of white deaf as nonwhite deaf graduated from a school for the deaf (Lunde and Bigman, 1959). A third study found that five times as many white deaf as nonwhite deaf in Washington, D.C., receive any college education (Schein, 1968). None of these studies was specifically designed to investigate problems of nonwhite deaf persons. To date in fact, few studies on this population have been attempted.

\section{Psychological Aspects}

What effect does the dual minority status have upon the psychological development of nonwhite deaf persons? Do these persons generally relate more closely with persons of their own races or with other deaf persons? To the best of our limited knowledge, these questions have seldom been raised, let alone answered, by investigators in deafness.

In fact, the entire area of psychological aspects and problems of nonwhite deaf persons has been largely ignored. The data we are reporting may be suggestive, but because replicative studies are so conspicuously absent, they cannot be interpreted as conclusive.

Two important studies in the Los Angeles area provide much of our information. The first, a 1967 effort by Ernest Hairston and John Bachman, examined the lifestyle of Negro deaf persons in Los Angeles. The second, by Linwood Smith, investigated the small "hardcore Negro deaf adult" population in Watts.

Both found that the greatest problem of the subjects was communication. The Black deaf persons studied were largely isolated. Smith found that none of his subjects knew any of the others in the study, despite the fact that all lived within a few blocks of each other. They appear to live practically invisible lives. As Smith observes, this social isolation and invisibility constitute an intellectual deprivation far in excess of that one might attribute to deafness alone. They are neglected and desperately in need of help, 
EDUCATIONAL, PSYCHOLOGICAL, AND OCCUPATIONAL ASPECTS OF THE NONWHITE POPULATION

yet incapable of making their needs known and of seeking assistance.

Smith and Hairston and Bachman agree that Black deaf adults customarily regard deafness as more handicapping than blackness. The hardcore deaf Negroes-those with especially meager communication skills, minimal education, and large unemploymentare often not accepted by the more fortunate Black deaf. Additionally, these persons appear to be untouched by the social movement taking place among Blacks throughout the country today. The Black community has yet to take an interest in deafness. Smith observes that lack of communication may be the major cause of these problems.

A study by Furfey and Harte (1968) of interaction between deaf and hearing persons in Baltimore, Maryland, confirms this data on communication. They found that half the nonwhite deaf persons surveyed rated below average in communication with deaf persons, and half below average in communication with hearing persons, as compared with other deaf persons in the study. By contrast, only 15 and 17 percent of the white deaf studied were so rated.

That other deaf persons often do not accept nonwhite deaf persons is also confirmed by several studies (see Bowe, 1971b). Clubs for the deaf in several cities exclude nonwhite deaf persons from membership explicity or implicity. Repeatedly, in city after city, we observe several circles of social life among deaf persons. The highly eduated white deaf adults move in one circle, the less highly educated white deaf in another. This pattern appears to hold for the nonwhite deaf groups as well. Rarely do the groups mix racially.

A kind of "indirect discrimination" results from this arrangement, in that nonwhite deaf persons often do not learn of educational, vocational and social opportunities available for deaf persons in their areas. Their low representation in clubs for the deaf, coupled with their lack of visibility, means that studies often miss them, as do rehabilitation case-finders. Inferior service results.

Very little is known about the intelligence of nonwhite deaf persons. The few studies we have seen indicate, depressed scores as compared to other deaf persons and to hearing persons. The validity of this gap is questionable, its reasons unknown.

The picture emerging from the data on psychological aspects of nonwhite deaf persons is one of people cut off from the hearing 
36 EDUCATIONAL, PSYCHOLOGICAL, AND OCCUPATIONAL ASPECTS OF THE NONWHITE POPULATION

community by deafness, from the deaf community by race, and from help they urgently need from service agencies by indirect discrimination. Exactly what effects this isolation has upon these persons is not known, but some effect is certain.

\section{Occupational Status}

Severe under-education appears to be a major factor in the gross under-employment and high unemployment found among many nonwhite deaf persons. According to Schein's figures (Schein, 1968) on the noninstitutionalized deaf adults of Washington, D.C., who were in the labor force, we can make these observations: 1 in 5 white deaf persons occupies a professional-technical position; by contrast, fewer than 1 in 50 nonwhite deaf persons does. Half the white deaf women are found in clerical-sales positions; only 1 in 25 nonwhite deaf women holds such a post.

Schein also found that the unemployment rate for nonwhite deaf men in Washington, D.C., was almost four times the rate for white deaf men. Regarding women, 10 percent of the white deaf women in the study were unemployed, but almost half the nonwhite deaf women were.

Lunde and Bigman (1959) report similar results for their national survey. Crammatte (1968) uncovered "no Negro deaf professionals other than teachers . despite diligent efforts." Since his study in the late fifties, however, at least four Black deaf professionals have entered the field of deafness. These individuals are currently making important progress in bringing services to increased numbers of nonwhite deaf persons.

As for earnings among nonwhite deaf persons, Schein (1968) found that the median income of white deaf men in Washington, D.C., was $\$ 6,473$ which contrasts with $\$ 2,611$ for the nonwhite deaf men. The white deaf women in the survey reported a median income of $\$ 3,542$ while the nonwhite deaf females had a median of $\$ 990$. Comparable figures were obtained by nonwhite deaf respondents in the Lunde and Bigman study (1959).

Smith (1971) observed that the hardcore Negro deaf adults he studied were generally afraid of agencies and refused to approach the Division of Vocational Rehabilitation even when informed of services available. He summarizes his observations in this passage:

When the hardcore adult's deafness, racial background, lack of verbal expression, meager education, poor job attitude, poor selfconcept, and unrealistic goals are brought into the rehabilitation 
EDUCATIONAL, PSYCHOLOGICAL, AND NONWHITE POPULATION

occupational aspects of the

picture it generates a mass of confusion and the client finds it difficult to get retraining services and eventually is marked off as non-feasible.

\section{Conclusions}

This paper has considered some information currently available on the nonwhite deaf population. It has hopefully spotlighted the fact that crucial data on this group are entirely too meager. Some aspects requiring further investigation include the prevalence of racial discrimination within the deaf community and means for increasing integration; how to enrich education for inner city and ghetto deaf persons, particularly in the realm of preschool education; improving case-finding techniques for use in the inner city; detailing some of the salient characteristics of nonwhite deaf persons demographically; increasing Black involvement in affairs of the deaf; studying the psychological effects of deafness and race together on nonwhite deaf persons; describing the special problems of nonwhite groups such as Indians and Orientals, with proposed solutions to these problems; exploring the effects upon Puerto Rican deaf children who have Spanish-speaking parents of the school requirements upon oral education in English only; and increasing the numbers of nonwhite deaf and hearing professionals serving in the field of deafness.

Several of these efforts will of necessity be focused exclusively upon certain nonwhite deaf groups, while others involve integrated services. In the area of intelligence, for example, IQ in deaf persons has been studied extensively with more than fifty investigations reported in the literature over an equal number of years (Vernon, 1968). However, researchers controlled for the variable of race in almost every case. In effect this means that our data on intelligence in deaf children and youth is for the most part confined to white deaf persons. Many comparative studies on the mental abilities of white and nonwhite deaf persons are needed before we can make any definitive statements about their mean IQ's.

Coming to the fore for the first time are highly qualified Black deaf professionals such as Ernest Hairston of Washington, D.C., Glenn Anderson of Detroit,, Katie Brown of Chicago and Linwood Smith of North Carolina. These individuals have the potential to provide inspired leadership in this area for decades to come.

It is a cause for grave concern that so little has been done for this group, that vast cobwebs of indifference and apathy continue to 
exist among professionals and laymen alike with respect to the gross under-education, mass under-employment, and severe social isolation of nonwhite deaf persons. Hopefully, this decade will see improvements in the delivery of services to this population. As James F. Garrett said in his keynote address to the 1970 PRWAD convention in Rochester:

The deaf who have been served thus far, whether we like to accept it or not, are not the deaf who are in most need. Our problem and our challenge in the next ten years is to do a job and to do as good a job on those deaf who are most in need as we have been doing with the others that we have been serving. The deaf who are poor, who are hidden away in our inner cities and in our ghettos, and particularly the black deaf, are individuals who need service and who must be given equal opportunities to enjoy the fruits of everything we have learned. (pp. 28-29)

\section{REFERENCES}

Babbidge, H. D. Education of the Deaf: a report to the Secretary of Health, Education and Welfare by his Advisory Committee on the Education of the Deaf. Washington, D. C.: U. S. Department of Health, Education and Welfare publication, 1964.

Bowe, F. G. "Some Observations on the Education and Rehabilitation of Black Deaf Persons." Paper delivered to the 45th Meeting, Convention of American Instructors of the Deaf, Little Rock, Arkansas, June 28, 1971. (To be printed in the Proceedings.)

Bowe, F. G. Nonwhite deaf persons: educational, psychological and occupational considerations. American Annals of the Deaf, Vol. 188, June 1971, pp. 357-361.

Crammatte, A. B. Deaf Persons in Professional Employment. Springfield, Ill.: Charles Thomas, 1968.

Furfey, P. H. and Harte, T. J. Interaction of Deaf and Hearing in Baltimore City, Maryland. Washington, D. C.: Catholic University of America, 1968.

Garrett, J. F. Keynote Address to the Conference of Professional Rehabilitation Workers with the Adult Deaf, Rochester, N. Y., October 12, 1970. Printed in the Proceedings, Journal of Rehabilitation of the Deaf, Vol. 4, January 1971, 23-29.

Hairston, E. and Bachman, J. "A Study of a Segment of the Negro Deaf Population in the Los Angeles Area." Leadership Training Program in the Area of the Deaf, 1967. 

EDUCATIONAL, PSYCHOLOGICAL, AND OCCUPATIONAL ASPECTS OF THE
NONWHITE POPULATION

Lunde, A. S. and Bigman, S. K. Occupational Conditions.Among the Deaf. Washington, D. C.: Gallaudet College, 1959. Schein, J. D. The Deaf Community. Washington, D. C.:Gallaudet
College, 1968.

Smith, J. D. "The Hardcore Deaf Negro Adult in the Watts Area of Los Angeles, California." Leadership Training Program in the Area of the Deaf, 1971. 